\title{
The Last Word. Why the Timing of the World's Religious Writings Matters
}

\author{
Michael James Fantus \\ Washington DC, USA \\ Email: michaeljamesfantus@gmail.com
}

How to cite this paper: Fantus, M. J. (2019). The Last Word. Why the Timing of the World's Religious Writings Matters. Open Journal of Philosophy, 9, 252-264. https://doi.org/10.4236/ojpp.2019.92017

Received: April 15, 2019

Accepted: May 27, 2019

Published: May 30, 2019

Copyright $\odot 2019$ by author(s) and Scientific Research Publishing Inc. This work is licensed under the Creative Commons Attribution International License (CC BY 4.0).

http://creativecommons.org/licenses/by/4.0/

\begin{abstract}
Humanity and its gods evolved collinearly to the cultures, capabilities, politics, climates, and conditions that influenced it. Causes and effects always precede one another, history tells us how things turned out and gives us an opportunity to reflect on what might happen next. Where religious history is concerned, this is apparently not the case. Humanity has been manipulated, fooled, and denied the chance to know what really happened to it during its long struggle with understanding God's Will and His place in our lives. Given the chance to know the truth, how eagerly would we embrace it? Fortunately, the news is good. The Kingdom of Israel, led to the heights by Solomon, fell to a desperate and brutal culture, the Assyrians. Their God, Ammon, later called Yahweh, was forced upon them as was His fickle, often violent temperament. This led to almost a thousand years of stark changes in Hebrew religious practices which resulted in the myths and legends of the Deuteronomy, what modern Jewry calls the Torah. The ideas, poems, and scriptures of Solomon, a devotee of the Evening Star Goddess Ishtar, most of which are focused on ways to revel in this lifetime offer a sharp contrast to the disaster-prone way of life of the Jews in the Torah, and the harsh rules-based way of life Yahweh expected of them in exchange for His Refuge. So said a man named Moses who left not one word of fact or truth behind him. Still he had advocates, as did Saul of Tarsus, the man who created Christianity, at least until his colleague, St. Mark-Peter gave us Christ's Commandments as a Pole Star to guide us out of the madness of all the false prophets of the past. St. Matthew said it well about St. Mark's Vision of Christ: "Upon these Words, all other words hinge." This Essay, the Last Word frees us from the lies we have been told about our religious past, gives us the Truth and as with all truths, an amazing opportunity to find our way: A planet where neighbors love one another and give Thanks to God for the chance.
\end{abstract}

\section{Keywords}

Christianity, Bible, Torah, Qu'ran, New Testament, Old Testament, 
Hinduism, Solomon, Moses, Noah, Deuteronomy, Islam, Inanna, Isis, Ishtar, Mesopotamia, Cuneiform, Israel, Jesus Christ, Judaism, Gospels, St. Mark, Book of Revelation, St. John, God, Judaism

\section{Introduction}

Does the order in which things happen matter? Any forensics professional, chemist, physicist, doctor, lawyer, or chef will tell you yes. A history professor, likewise, is not credible unless he teaches the facts in sequential order and properly explains the causes and effects that interlace them.

Any attempt to omit or re-sequence history is malpractice to say the least, a mortal sin to be sure-on this all reasonable persons agree. Unless it involves religion, then all the rules fall away, become irrelevant. God's oversight and insights through His Words are timeless, termless, and only a fool would question the need for a proper perspective on their relationship to human evolution.

Religion is as old as human civilization as is the capability of both for delusion. It is the path and purpose of inquiry into the Divine Mystery, however, to unearth Truth, no matter where it is hidden and make use of it to solve the problems of the human condition, to cause it to bloom into a thing of beauty. This process of beautification begins with the beginning, follows the path the past laid down, and an intelligent and reasonable set of conclusions to determine the implications for now.

\section{What Happened, What Didn't, What We Know, What We Don't}

We don't know everything that happened, but we know quite a lot. When we're unsure, it's because we lost something, it was misplaced, or someone wanted it to be lost. Much of the time, accidents happened. Fires, floods, time itself eroded at documents and artifacts, other times books and scrolls were appropriated and never returned Yurtoğlu (2018).

Sometimes it was an act of God, sometimes not. Most of the time, it was politics, other times it was war Barile (2018). When it's not time, a side effect of armed conflict and invasion, what causes history to become misplaced, or worse, displaced?

\section{Why Does Revisionist History Take Place?}

Revisions to the historical record take place for several reasons Pavlac (2010). For political purposes, it is done to preserve order, protect the "innocent", to preserve political ideology, or constructively, to discredit past misinterpretations as new interpretations arise.

For which of these reasons might clergy or an institution engage in such tactics? Rather than restate the ways control of liturgy is synonymous with political 
dominance and social power Raven (1999), I wanted to see what happened to humanity organically by examining its religious history one fact at a time, exactly in the order in which they took place. How that differs from what has been published is very interesting.

\section{The Conversation between God and Man}

Since around 3200 human beings have written stuff down Schmandt-Besserat, (2014), for reasons ranging from management of accounts, facilitate the development of spoken language, represent abstract data in concrete form and for religious purposes. Today we call some of this writing "scripture" in spite of our lack of concrete or complete understanding of the motivations of the authors.

Most of the time when something was written and printed, scripture was not the intent Kruger, (2012). As Kruger says, "Sometimes, even in the academic world, things get said so many times that people assume they are true. And when that happens, no one bothers to look at the historical evidence in a fresh way".

What then is the transformational process writing undergoes from words on a page to the Word of God and how do we migrate from the rote habit of believing it is true to rooting in what we Know for sure is Scripture or Truth Transcribed? The Messengers of God Themselves said to Know God, all one has to do is pay attention to the Signs.

\section{The Signs}

Persons gifted with insight into the "signs" are called "warners" in the Qu'ran, prophets in the Bible and Torah, Rishis in Vedanta, Lamas in Buddhism. The Christian tradition is the only one to insist its scriptures are "God Inspired, written by man." Kruger says this was not the intent at the time they were written nor were Biblical writings treated as anything other than practical.

He says further that the authors of the New Testament were aware they were writing for the upkeep of tradition and never attributed their penmanship to the unseen Hand of God.

Still we say that it is.

2 Timothy 3:16:

All Scripture is God-breathed and is useful for teaching, rebuking, correcting and training in righteousness.

Yet, Schneidewind (2008) says it was not. When societies in the Judaic Traditions transitioned from nomadic to agrarian, writing replaced the oral tradition and books were born. Scriptures were collections of stories and lessons passed down through transmission, and then later became mistaken as God's Word.

This was very helpful to the priests who kept politicians in power and vice versa as we noted earlier. The old stories and the new alike were used to levy the will of the gods and their patrons, the Ruling Class. "God Inspired it is", they said to heretics and still say, “or else ...!” Medieval Inquisition Torture (n.d.).

It doesn't matter if it's true so long as you don't know, deny what you've been 
told, per the Catholic Code of Canon Law. Don't worry, we got this, and it's all good. So, if it is all God Inspired and, under pain of death and done right for our own good, does the order of scripture make a difference?

\section{What Came First?}

It is not clear whether the Egyptians or Mesopotamians were the first to produce written religious material Mark (2018). Religious writing in Egypt has been dated as early as circa 3500 BCE (Before Common Era). Through rough translation, we have come to think that Egyptian writing indicated they believed that the objects in their proximity were of divine origin or purpose, and their veneration was used to confer blessings through worship or gain control over them, Dunn (n.d.).

This lasted until the Upper and Lower Kingdoms united and then, around 3150 the Pharaoh, His Name was Menes, became God Mark (2019). It was clear "this man balanced Egypt by conquering the forces of chaos and presiding over a land of order".

The generally pervading idea that emerged this, called Ma'at, or harmony was integral to religion, society, and culture. Ma'at asserted that there was a balance that existed between gods, men, society and of course between all else and the affairs of the Pharaoh. The objective of religion was to acknowledge the benefits of and preserve the integrity of Ma'at.

Even still, there was a great deal of class war in Egypt, and armed conflicts between the Upper, Lower and Middle Kingdoms. This affected whose ideas of what was and was not a god. The outcomes, the victors and those whose records survived have given us an idea of when certain gods and goddesses first appeared:

Isis-Circa $2700 \mathrm{BCE}$

Ra-2500 BCE

Osiris-2400 BCE

Horus-2350 BCE

While the Egyptians can be credited with scrawling the first characters of written and spoken language, and their gods and goddesses are fan favorites even to this day, they did not create the First God.

\section{Cuneiform and the First God}

Cuneiform is the first written form of communication. Its authors, the Sumerians, began using it around $3500 \mathrm{BCE}$. It entered its most refined form in 3200 BCE. Unlike Egyptian hieroglyphs, cuneiform was used by Sumerian scribes in the ancient city-state of Uruk, in present-day Iraq, primarily as a means of recording transactions, Mark (N.D.).

Before it could write however, Sumer created images of humanity's first god, a winged goddess named Inanna "the Evening Star", whom the Egyptians later called Isis. There is a temple dedicated to her that dates to 5000 BCE, Sylvestra, 
(2012) in present day Al Muthanna Province, Iraq, near the border with Saudi Arabia.

So now we have a new timeline and new location, and our very first idea of Divinity this Innana, the Evening Star, also called “The Gate to Heaven”. Innana and Isis are clearly the same being with different representations through varied media, geographies and culture. Both are shown as women in the prime of their years, both have wings, both are associated with the sun, the moon, stars, and the protection of the living and the dead. She's obviously still very special to us. We've revered Her for more than 7000 years.

A key difference between Egypt and Mesopotamia was the Pharaoh, of course. In Egypt, the Pharaoh (2004) was regarded as a man, god, and monarch, Scala (2019). Reshafim.org. In Mesopotamia, however, Innana and the gods were viewed as humanity's partners. The Sumerians believed, as Brendan Nagle writes "Humans were created, in fact, for this very purpose: to work with and for the gods toward a mutually beneficial end" Mark (2011).

There was another culture learning to use the pen around this time of prehistory too, the Jews. What they believed ... is unbelievable.

\section{The First Evidence of Jews}

Alongside the Egyptians and Sumerians we find evidence of another Mesopotamian culture that wrote stuff down too, the Hebrews, Circa 3500 BCE, Bower (2016). In addition to writing, all three cultures shared something else: a certain winged goddess that the Sumerians called Innana, the Egyptians, Isis, and the Hebrews Astarte or Ishtar.

\section{The Mother of the Kingdom of Israel}

Worship of Ishtar and a pantheon of gods and goddesses was prevalent in Ancient Israel as it was with its contemporaries the Babylonians and Assyrians and the many other civilizations and cultures they liked to fight with Jones (2012). We know Solomon (970 BCE to $931 \mathrm{BCE}$ ) revered Ishtar, 1 Kings, 11:5, and so did his mother and King David's wife, Bathsheba (1000 BCE) Pinsky (2008).

Something or someone happened between the appearance of the First Jews in 3500 BCE and the disappearance of their Kingdom and its Patron Goddess. His name was Isaiah. Welcome to hard times.

\section{The First Book}

The First Book written in the Judeo Christian Tradition was crafted by the prophet Amos in $796 \mathrm{BCE}$, and his son Isaiah wrote First Isaiah afterward, 2700 years after the early Jews started to write. Amos, the very first Author of the Books Bible, speaks of a pantheon of gods-among them, Ammon-the Sky Father from the land of Edom, a holdover from Northern African/Mesopotamian pantheons. There are many others.

The Real God, however, has yet to appear, but He definitely started to mate- 
rialize out of Ammon, a solitary and temperamental Sky Father, who unlike the Sumerian Gods, is a whole lot of no fun. Still the Jews rejected them and embraced Him see First Isaiah 1:1-9, circa 800 BCE Biblica (2016). Verse 9 explains it all: "Except the LORD of hosts had left unto us a very small remnant, we should have been as Sodom, and we should have been like unto Gomorrah".

What happened? Why did the Hebrews abandon Ishtar, the sweetest and most affectionate Goddess in Heaven for this “Lord of Hosts"? It wasn't illegal sexuality or abuses of hospitality. The Jews were scared of falling victim to the legendary fate of Sodom and Gomorrah, sacked and burned by the Assyrians.

Things went badly for the Nation of Israel against the more numerous and more organized Assyrians who burnt the Twin Cities to the ground and were not the least pleasant in their disposition under any circumstances, and their impending conquest of the world made the Jews think this meant God hated them. In any case, they didn't have a choice. Ammon, called the Lord Your God, perpetually dyspeptic over you, was here to stay.

Thank God for Eve, who took the heat off.

Race ahead 600 years to the Book of Genesis and the Jews still suck in God's eyes, but not because of their tendency to lose wars to other pagans this time, it's Eve's fault. And Here comes Moses to explain why.

\section{Moses}

The legendary slave master of Israel, Ramses II lived 1279-1213 BC. The Torah, the Law was written by "Moses" in $250 \mathrm{BC}$. Moses never met the guy or his father, Seti I, who lived 1279-1190 BCE, Britannica (2014). "Moses" was a total fraud. If we can't trust him about the freeing the Jews from slavery in Egypt, why should we listen to the rest of his thoughts on how Creation happened, how that harlot Eve fouled it all up for us, or give any of our attention to all those stories in Genesis, Exodus, Diaspora, and Reformation that he concocted?

When we read the Books of the Old Testament in order we see God's disposition toward us has always been rather brutal, but not particularly misogynistic or homophobic till 600 years passed and Moses came along. David and Solomon both had male and female lovers and were quite satisfied with both. Read an unabridged, authentic translation of the Hebrew Song of Songs that has not been touched by Christian hands. Then read the Bible and see how its other contributors, like Moses, turned Solomon's lush pastures of the human body into a toxic wasteland, and said let it be so on God's Authority.

\section{Moses's Version of Sodom and Gomorrah}

There is speculation that the Twin Cities of Sin were destroyed by around 1800 BCE (Never Thirsty). The sparse facts indicate, if they existed at all, they were burnt to the ground by the Assyrians, possibly dried up and disappeared due to drought conditions.

Isaiah as I mentioned in $790 \mathrm{BCE}$, said war and conquest were the causes of 
Sodom and Gomorrah's demise. Moses changed this. In 250 BCE, said in Genesis 19 that God Hates Fags, and destroyed Sodom and Gomorrah because of anal sex between men. This was 1500 years after their actual demise by the Assyrian army.

Also out of sync with history are the books of the Old Testament are Moses's Torah, which is a collection that hosts the Books of Genesis, Exodus, Leviticus, and Numbers. They are not the first as the Bible of today portrays them. If we number these correctly, with Amos as Book 1, the Books of the Torah begin with \#19. We don't know if "Moses" knew about the Books prior to his or cared about their sequence, but we know other people did, and they the Gutenbergs chose a non-sequential order.

\section{The Gutenberg Bible}

The logic behind the current order of the Bible, which was compiled and published by the Gutenberg Brothers for the first time in 1453, is based on the authority or weight of the Prophet that wrote their verses Grace to You (2016). The importance of the scripture determined its place in the order. It also mattered if the scripture was a poem or relayed the Law.

Saint Jerome had different ideas about this Patton (n.d.). In A.D. 391 he said we should compile scriptures "As, then, there are twenty-two elementary characters by means of which we write in Hebrew ... so we reckon twenty-two books, by which, as by the alphabet of the doctrine of God, a righteous man is instructed ..." About this, E. W. Bullinger in his Companion Bible made this bold statement: "Our English Bibles follow the order as given in the Latin Vulgate. This order, therefore, depends on the arbitrary judgment of one man, Jerome. All theories based on this order rest on human authority, and are thus without any true foundation."

That's arbitrary to say the least and doesn't tell us what we want to know: How did humanity respond to its own religious and spiritual traditions as it aged into the present time, and what can we learn from finding out?

If we used scientific method to discover the answer, and looked at the Books of the Bible in historical order and so draw conclusions about their role in shaping human history we would see this:

From 800 BCE to Circa $1 \mathrm{CE}$.

1) Amos (796 BCE)

2) First Isaiah (1-39)

3) Hosea

4) Micah

5) Nahum

6) Zephaniah (609 BCE)

7) Habakkuk (605 BCE)

8) The Deuteronomy: Joshua, Judges, Samuel, Kings (586-520 BCE)

9) Obadiah (586 BCE) 
10) Ezekiel (571 BCE)

11) Haggai (520 BCE)

12) Malachi (500 BCE)

13) Song of Songs (around 500 BCE)

14) Chronicles (350 BCE)

15) Deuteronomy Expansion Set

16) Jeremiah

17) Psalms to 89

18) Torah: Genesis, Exodus, Leviticus, Numbers (250 BCE)

19) Ezra-Nehemiah (250 BCE)

20) The Rest of the Palms-Started circa 330 BCE, but finished by 164 BCE

21) Second Isaiah (40-55 BCE)

22) Third Isaiah (56-66 BCE)

23) Jeremiah

24) Zechariah

25) Job

26) Ecclesiastes

27) Jonah

28) Daniel

29) 4 Maccabees

30) Tobit

31) Judith

32) Esther

33) Proverbs-all by second century BCE, first Century CE.

34) First Thessalonians (c. $50 \mathrm{CE}$ )

35) Galatians (c. $53 \mathrm{CE}$ )

36) First Corinthians (c. 53-54 CE)

37) Philippians (c. 55 CE)

38) Philemon (c. $55 \mathrm{CE}$ )

39) Second Corinthians (c. 55-56 CE)

40) Romans (c. 57 CE)

41) Revelation of Saint John, (68 CE)

42) Gospel of Mark (70 CE)

43) Matthew and Luke (by $100 \mathrm{CE}$ )

44) John (100 CE)

\section{Out with the Old, in with the New}

Isaiah called His God "Yahweh" or the Hammer that Smites the Anvil in Isaiah 41:7.

Moses used a different term for Him in Genesis and calls Him "Elohim" or "My God", but in any case, He's never been called "nice".

That brings us to History's Nicest Guy, Jesus Christ, and the meanest, Saul of Tarsus. Both said they God told them to replace the Old Law with the New. 
The Four Gospels never mention a man named either Saul of Tarsus or Paul the Apostle, nor the Apostles or their Acts. How could they have overlooked them?

St. Mark-Peter was even one of Saul's students and colleagues Pope (2018). How is it the First Gospel, written by a known associate of Saul of Tarsus mentions him even once?

St. Mark was trying to save us from this horrible awful man. The contradictions between St. Mark's Jesus Christ and Saul's are startling, as are the historical facts.

Most of us think Jesus was born late on Christmas Eve in Year 1. He was born in $5 \mathrm{BCE}$, died in $30 \mathrm{AD}$. After Jesus Died, Saul of Tarsus apparently saw Him on the road to Jerusalem and gained Spiritual Eyesight. Using his new magic Jesus powers, Saul wrote a bunch of letters to various contacts around the Empire to ensure that women knew to shut up and do what they're told and that gay men were not part God's Plan except as the beneficiaries of punishment for their "errors".

Jesus said none of these things. Saint Mark's Gospel said Saul was the one in error instead. Who was this Saul of Tarsus? Saul of Tarsus, the Magician, was also called Saul the Jewish Pharisee and then Saint Paul the Christian, was born in $5 \mathrm{CE}$ in Tarsus Turkey. He never met Jesus, never once read the Gospels. The first Gospel, Mark, was written by Mark Peter in 70 AD 6 years after Saul's death in circa 64 AD. Still, Saul says in 1 Corinthians 15:1-2:

1) Now, brothers and sisters, I want to remind you of the gospel I preached to you, which you received and on which you have taken your stand.

2) By this gospel you are saved, if you hold firmly to the word I preached to you. Otherwise, you have believed in vain.

Mark, Matthew, Luke and John don't bring him up even once between them, and they succeeded him by several decades. Still, Saul who called himself "Paul" wrote "letters" that are called the Word of God and "Truth". Why would the Authors of the Gospels omit him and all the content of the Epistles, if not contradict them outright if They believed they were God's Word?

Were the Authors insane, heretical, deviant and perverted or were they trying to help us out?

For this all important question, we turn to He Who Takes Away All of Life's Troubles, God's Son, Jesus Christ.

\section{The Real Jesus Christ}

The Real Jesus did not hate women, gays, poor people, immigrants, the sick, the vulnerable or outcaste. He loved to party, drink and eat, did not care about the Sabbath or keeping it holy, valued the accumulation of friends instead of money, did not condemn anyone for any reason unless they were stingy with their money.

Jesus had simple and sound advice. "Love God, Love Everyone Else Just The 
Same", Matthew 27: 37-40, and that This created the Kingdom of Heaven. "Paul", however taught that murdering Jesus was the ticket ... if you could afford to pay the membership fee-1 Timothy, 6: 17-18.

We have been confused over which way is best for thousands of years but we're not done yet.

\section{The Chronological Order of the Rest of the World's Great Verses}

The world has benefitted from the efforts of many good and noble men and women who took it upon themselves to ask God's Spirit for assistance with all the matters that troubled it.

1800 BCE The Rig Veda is written. 3 more are later added, the Sama, Yajur and Atharva.

1500 BCE The Greek Civilization adapts the essence of neighboring Zoroastrian and Indus.

Valley legends along with others into legends and myths that partially explained the Order of Creation. They regularly debated how mankind could exceed the mischievous and sensual nature of the gods who unlike men, could act with impunity.

1300 BCE the Aztecs define their existence relative to the whims of a pantheon of gods whom they feel love and hate them in degrees of divine magnitude relative to their observations (and experience) of the human sort.

560 BCE Siddhartha Gautama addresses a decadent and declining Hindu civilization with His revolutionary idea that serving the needs of others results in peace and prosperity for oneself.

500 BCE The Ramayana, the epic of the godhead Rama is written to extol upon the virtues of lawful behavior and how acts of heroism can sustain society during its darkest times.

In 400 BCE Sokrates counsels the hero Bellerophon regarding his plans to marry his boyfriend Cyrus the Younger.

At the same time, 450 BCE The Bhagavad Gita is written. Sri Krishna, the emissary of the God of Victory, Kartikeya, descends from Beyond to turn the tide against a tyrant King that cheated his way to the throne.

300 BCE Rome surges out of the remnants of war torn Greece. Rome prides itself on its "more is better" perspective on just about everything and creates the most diverse pantheistic culture ever known. Around the same time, the Torah, including Genesis, Exodus, Leviticus, and Deuteronomy are written.

4 BCE Mari and Yusef, a young couple from Medea, give birth to Yshua, the man who spawns the legend of the Messiah, Jesus Christ. 30-33 CE, Yshua the son of Mari and Yusef is tried and executed for desecrating Hebrew Temples.

50-67 CE, Saul of Tarsus starts a new religion and writes the Epistles, 68-70 CE, The Revelation of Saint John is written. The first Gospel of Mark is dated approximately $70 \mathrm{CE}$. 
$100 \mathrm{CE}$ the Gospels of Luke, Jonathan, and Matthew are written.

320 CE the Council of Nicaea meets to determine the State Religion of Rome after rabble rousers from the Cult of the Christ, vast in numbers, demand full citizenship based on being human rather than ownership of wealth, property, or military service, threaten the stability of the Roman Empire.

570 CE the Prophet of Allah, Muhammad of Clan Quraysh enters a cave, and retruns with $\mathrm{Al}$ Qu'ran al Kareem, the Very Best Verses, which instruct in "A Sound Path for Those Who Reason." The rest is Stet.

This comes at a price: civic responsibility. The First Muhammad insists and elucidates upon the Presence and beauty of the Design for Life by a Merciful God and asks all of us to share in His Bounty. Others calling themselves $\mathrm{Mu}$ hammad add to his Verses: in 800 CE Surah Al Baqarah is written, and $1000 \mathrm{CE}$ Surat Ali Imran follows and finally in, 1200 CE comes Surah An-Nisa.

1095 CE the Crusades, the wars of aggression of the Holy Roman Catholic Church against Islam begin. They never end.

1100-1200 (approx.) the Kitab al Jilwa is written. The Kitab al Jilwa is the Book of Revelation of the Yezidi, an Arab, Kurdish, Eastern Europeanreligion that reveres the King Angel, TawsiMelek, AKA the Archangel Michael as its deity.

1453 CE the first Bible is published.

1469 Guru Nanak founds Sikhism.

1829 The American Joseph Smith authors an “Additional Testament of Jesus Christ".

1933 the Holocaust begins. Over 6,000,000 million are murdered in unprecedented holy war waged by Christians against the rest of the world. Some say it never ended.

1945 the first nuclear weapon is deployed by the United States of America.

2003 Shock and Awe The human preponderance for violence and conquest has not dimmed over time.

\section{Conclusion}

We've come a long way since the first man or woman invented, worshipped and wrote about Innana, to now, to the end times. The world is in its last decade of comfort and naivete, and then humanity and all life begin a rapid slog into End Times brought on by itself and no other, Winston (2019).

Human failure and unwillingness to acknowledge the teachings of history and the wisdom of its sages have clearly resulted in massive losses of rare and unique human, plant, animal individuals.

The future of life on earth and the shape and condition of the planet itself are questionable due to the failure of humanity to respect and honor its Divine Creator and heritage and listen to the guidance of its Prophets-those that are the honest at least.

This is not new; human beings have always felt fragile amongst our own kind, 
have always asked God for guidance on how to endure and exceed the conditions we create and find instead the Divine Glories inherent in the beliefs of our ancestors.

We're witnessing and hiding from the consequences of our actions these past 7219 years of human existence and why we are doing so is not one of the questions we ask.

Maybe because we think life will go on, possibly because we feel comfortable with the Reign of the Hammer and the Anvil of Isaiah and the False God of Saul of Tarsus. Maybe we think we have no other choices or have nothing new to learn about ourselves or our Maker.

This is an error we can address at any time and incorporate the wisdom of the Gospels immediately if we want.

The Authors of the Gospels in particular were rooting for us and sought to give us every advantage to achieve a beauteous destiny through the Personality and Teachings of Jesus Christ.

They knew God had an unyielding loved for humanity and His Only Request of us is to be fair and good towards one another. Upon our willingness to do this, "All Things Hinge" (Matthew 22: pp. 37-40).

Ye Xode e TawsiMelek

The Most High Watches Over Us.

\section{Conflicts of Interest}

The author declares no conflicts of interest regarding the publication of this paper.

\section{References}

(n.d.). Medieval Inquisition Torture.

http://www.medieval-life-and-times.info/medieval-torture-and-punishment/medieval-i nquisition-torture.htm

Barile, D. (2018). The Top Ten Most Important Ancient Documents Lost to History. https://www.smithsonianmag.com/history/top-ten-most-important-ancient-document s-lost-history-180967495

Bower, B. (2016). Oldest Alphabet Identified as Hebrew. http://www.sciencenews.org/article/oldest-alphabet-identified-hebrew

Britannica, T. E. (2014). Seti I. https://www.britannica.com/biography/Seti-I

Dunn, J. (n.d.). The Origins of Egyptian Religion. Tour Egypt. http://www.touregypt.net/featurestories/religiousorigin.htm

Grace to You (2016). Why Are the Books of the Bible in the Order They Are in? Are They Listed Chronologically? http://www.gty.org/library/questions/QA174/why-are-the-books-of-thebible-in-the-or der-theyare-in--are-they-listed-chronologically

In What Years Were Sodom and Gomorrah Destroyed? NeverThirsty. https://www.neverthirsty.org/bible-qa/qa-archives/question/in-what-years-were-sodo $\underline{\mathrm{m} \text {-and-gomorrah-destroyed/ }}$ 
Jones, L. E. (2012). Ishtar (Assyro-Babylonian Deity).

https://search.credoreference.com/content/topic/ishtar_assyro_babylonian_deity

Love/AWL-Images, J., \& Scala. (2019). Egypt's Pharaohs Delivered Divine Justice from beyond the Grave.

https://www.nationalgeographic.com/archaeology-and-history/magazine/2019/01-02/e gyptian-pharaohs-laws-and-punishments/

Mark, J. J. (2011). Mesopotamian Religion. https://www.ancient.eu/Mesopotamian_Religion

Mark, J. J. (2018). Religion in the Ancient World. https://www.ancient.eu/religion

Mark, J. J. (2019). Menes. https://www.ancient.eu/Menes https://doi.org/10.20855/ijav.2019.24.1

Mark, J. J. (N.D.). Cuneiform. http://www.ancient.eu/cuneiform

Patton, J. W. (n.d.). The Inspired Order of the Bible. http://jpatton.bellevue.edu/inspired.html

Pavlac, B. (2010). Revisionist History, Positive or Negative? https://staff.kings.edu/bapavlac/methods/revision.html

Pinsky, R. (2008). The Life of David. New York: Nextbook/Schocken Books.

Pope, C. (2018). What the Story of St. Mark Teaches Us about Reconciliation. http://blog.adw.org/2018/04/story-st-mark-teaches-us-reconciliation

Raven, B. H. (1999). Kurt Lewin Address: Influence, Power, Religion, and the Mechanisms of Social Control. Journal of Social Issues, 55, 161-186.

https://doi.org/10.1111/0022-4537.00111

Schmandt-Besserat, D. (2014). Denise Schmandt-Besserat. https://sites.utexas.edu/dsb/tokens/the-evolution-of-writing

Schneidewind, W. (2008). Origins of the Written Bible. https://www.pbs.org/wgbh/nova/article/origins-written-bible

Sylvestra (2012). Inanna-Sumerian Mother Goddess, Queen of Heaven and Earth. 24 June 2012, Goddess Inspired.

https://goddessinspired.wordpress.com/2012/06/10/inanna-sumerian-mother-goddessqueen-of-heaven-and-earth/

Winston, A. (2019). The Story of Sustainability in 2018: "We Have about 12 Years Left". https://hbr.org/2018/12/the-story-of-sustainability-in-2018-we-have-about-12-years-lef $\mathrm{t}$

Yurtoğlu, N. (2018). History Studies. International Journal of History, 10, 241-264.

Http://www.historystudies.net/dergi//birinci-dunya-savasinda-bir-asayis-sorunu-sebin karahisar-ermeni-isyani20181092a4a8f.pdf

https://doi.org/10.9737/hist.2018.658 